IRA-International Journal of Education \& Multidisciplinary Studies

ISSN 2455-2526; Vol.07, Issue 02 (2017)

Pg. no. 99-102

Institute of Research Advances

http://research-advances.org/index.php/IJEMS

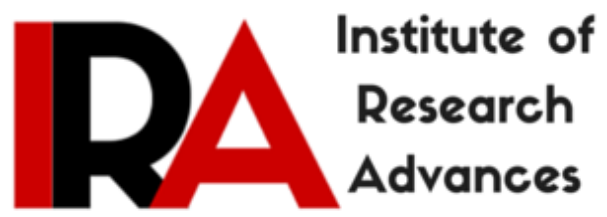

\title{
Pradyumnapur: The First Capital of Malla Dynasty: Mallabhum
}

\section{Sukanta Majumder}

Assistant Teacher of History, West Bengal, Bankura, India.

Type of Review: Peer Reviewed.

DOI: http://dx.doi.org/10.21013/jems.v7.n2.p6

\section{How to cite this paper:}

Majumder, S. (2017). Pradyumnapur: The First Capital of Malla Dynasty: Mallabhum. IRA International Journal of Education and Multidisciplinary Studies (ISSN 2455-2526), 7(2), 99-102. doi:http://dx.doi.org/10.21013/jems.v7.n2.p6

(C) Author.

\section{(cc) EY-NC}

This work is licensed under a Creative Commons Attribution-Non Commercial 4.0 International License subject to proper citation to the publication source of the work.

Disclaimer: The scholarly papers as reviewed and published by the Institute of Research Advances (IRA) are the views and opinions of their respective authors and are not the views or opinions of the IRA. The IRA disclaims of any harm or loss caused due to the published content to any party. 


\section{ABSTRACT}

Nirsinghadev was a great king of Pradyumnapur. In 694 AD (Bengali 101 Abdo), in Indradadashi Tithi, Raghunath's coronation had done at Pradyumnapur in front of God Indra and Panchanan Ghosal gave him the title as 'Malla' and Raghunath was known as Raghunath Malla. From that time started a new era 'Mallabdo' and Kingdome was known as Mallabhum. After 300 years and eighteen rulers of Mallabhum kingdom, capital was transferred from Pradyumnapur to Bishnupur.

\section{Introduction}

It was the time of summer, second half of Seven Century AD. A group of pilgrims were going to Purusattampur(now known as Puri,Orisa) to see the Lord Jaganath from Joypur of Rajasthan. In this pilgrim group a deposed rajput couple stayed and whose wife was pregnant when they were came to Lowgram(now $8 \mathrm{~km}$ away from north east side of Kotulpur Block ,Bankura, West Bengal, that time Lowgram was surrounded by deep forest). The Sun was beyond the west horizon. Rajput pregnant woman was feeling labour pain; she lay down under the tree and delivered a baby boy. After delivery she was died. Misfortunate king was confused what to do now. Then the king foreseeing difficulty of carrying a new born child with him, he decided to lay down the child under tree and for his identity the king gave a letter and a king-sword(named Joysankar) and went forword to purusottampur.

When the day light came a childless Bagdi widow went to the forest for collecting the fire wood. She saw a beautiful child laid down under the tree. (Locally it is a well known story that newly born child mother was never heard of; and whether she was devoured by wild beasts. There was a honey comb on the tree where the baby boy laid down, few drops of honey fell down to the baby's mouth which gave energy to survive). She took the infant and came to her home with the baby's identity and king sword. She reared him till he reached the age of seven, in the rituals and circumstance of Bugdi community. The Bagdi woman gave his name Raghunath. When Raghunath was seven his surrogate mother seriously ill and before her death she handed over Raghu with his identity and king sword (joysankar) to the great priest bramhin Panchanan ghosal. After that, Raghunaath reared by Panchanan ghosal and worked as a cow boy like other bagdi friends. Carrying the king-blood when he went to feed cows with the other cow boys he started wrestling with friends and practice physical exercise, battle acquirement.

One day Raghu was gone to feed the cows with other cow boys, one cow was stolen. Raghunath was searching the cow for long time but failed and he was so tired and he was asleep under a tree. After noon was running but Raghunath not came to the home so Panchanan was tensed and went to search for Raghunath here and there in jungle. Few times letter in the forest he saw Raghu laid down under the tree and a big cobra snake standing his colored hood to protect the sun light which felt down on the Raghunath's face. Bramhin thought that Raghu was died by snake bite .Hence he sought 'Raghu', Raghu.........The snake was went away and Raghu wake up. Looking at the scene bramhin priest was stunned and thought that the boy bearded king-sign. After that Panchanan arranged education for Raghu and obtained a promise from him that if he ever becomes a king he should be made his purohit (priest). From that time Raghunath ceased to be a cowherd.One day,while Raghunath was fishing with other boys at the village he caught bricks made by gold and'salgram' stone instead of fish, this was another sign of greatness in story that made him different from the general boys. When he was only $15 y e a r s$ old had no equal in wrestling in all the country round. This was one of the reasons to call him as Adi Malla or named as Adi Malla (malla means who done wrestling).

At that time Nirsinghadev was a great king of Pradmannapur (1.5km away side of Joypur, Bankura and locally called Podompur) who arranged a funeral feast,where Panchanan ghosal was also invited and he wasaccompanied by Adi malla.As Adi malla was not allowed to eat with 'bramhans' so he had to sit outside in the court yard. Nirsrinhadev was attracted by Raghu's appearance and the king held an umbrella over his head to protect Raghunath from sun and rain. A that time bramhans were said that since 
the king himself held the umbrella over him; the boy was destined to become a king one day. The king of Pradumannapur gave him a grant of Laugram and neighboring some villages.

There after Raghunath came back and his coronation had done at the place Rajdanga of Laugram and came out as a feudal lord. He enriched his power by cavalry, physical power and war art by the help of bagdi warriors. His power was scattered neighboring all feudal states and this news also reached to the king of Pradyumnapur. At that time Partapnarayan the feudal king of Jotbihar, (present day at Indus P.S,Bankura) who was under the Pradyumnapur kingdom, called himself as independent and deny to gave treasury. Nirsinghadev called Raghunath to stop that uprising. Raghunath tackled and stopped that revolt successfully and caught Pratapnarayan and brought him to Pradyumnapur and the King killed Pratapnarayan. For his valor, King announced, Raghunath as a feudal lord of Jotbihar.

That present time Nirsinghadev was very happy for the peacefulness of his kingdom. He decided to go pilgrim with his family and handover the all responsibilities to the Commander-in-chief. Coincidently this dishonest Commander-in-chief wanted to be king of Pradumannapur. For protection of treachery, Commander-in-Chief, Rghunath was lost his feudal states andmade him prisoner. After that Nirshinghadev came back to Pradyumnapur due to illness of his daughter, listen to all the incidents he was stunned and free Raghunath from the prison and gave all his feudalities. But Raghunath denied and went away from there. The king twitted the Chief-in-Commender but the Chief treacherously announced king was mad that's why had to be prisoned. This news appalled Rahgunath and he determined to punish the Chief but he was helpless that time. The day came when he met with a Santhal Commander who assured him to help regarding his matter and free the King from the prison. With help of Santhal warriors Raghunath attacked Pradyumnapur and murdered the Chief. But matter of fact, the king was truly mad because of long time being a prisoner. Then one day the King was suicide to Kanai Shayer (it's a big pond). Now even today this big pond is still exist with the same name. In this circumstance the Queen prudently married her only daughter, Chandrakumari with Raghunath and she was decided to be "Sati" with her husband. From that time Raghunath became the king of Pradyumnapur.

In 694 AD (Bengali 101 Abdo), Indradadashi Tithi with his old Santhali friends (warriors) in front of God Indra, his coronation had done at Pradyumnapur and Panchanan Ghosal gave him the title as 'Malla' and Raghunath was known as Raghunath Malla. At that time started a new era 'Mallabdo' and Kingdome was known as Mallabhum. So Pradyumnapur was the capital of Malla dynasty. Raghunath was the first prince of Malla dynasty, for this reason he also known as Adi Malla. He ruled Mallabhum from 694AD to 710AD (1 Mallabdo to 16 Mallabdo).

In his sixteen years of his reign, Adi Malla develop his kingdome area by the conquest some neighboring small forest states. At that time, Panchanan Ghosal (stapes father) was his mentor and guide. Adi Malla gave him the title as 'Mahapatra', after that he was known as Panchanan Mahapatra. Adi Malla was a contemporary of Sindhu State king, Dahir. Adi Malla was succeeded by his elder son Joy Malla who ruled his area from 16 Mallabdo to 26 Mallabdo. Joy Malla constructed the temple of Dandeswari at Laugram. At that place where snake was standing to protect the Raghunath, Joymalla, son of Adi Malla, founded Dandaswari temple which is present till the date. And where Raghunath got the gold stone and salgram stone, this place is known as "Sona Dohori" which is situated at Poyrag river at Laugram (Poyrag is the trebutary of Drakaswar river). And his other notable work, he founded a village Joypur (as per the story father was actually belonging to the place Joypur of Rajasthan), south side of Pradyumnapur after knowing his father's identity and story.

Joy Malalla was succeeded by his son Benu Malla in his time there was no change in Malla Dynasty. He ruled from 26 Mallabdo to 39 Mallabdo. Benu was succeeded by Kinu Malla and he was a strong ruler who took over the Indrohus (now named as Indus). He ruled from 39 Mallabdo to 49 Mallabdo. Fifth king was Indro Malla (48 to 63 Mallabdo). After that Kanu Malla(63 to 70 Mallabdo) was the king of Malla dynasty who conquered the kaktiya kingdom(present day patrasayar).Seventh ruler was Dha Malla (70 to 
81 Mallabdo).Dha Malla was succeeded by Sur Malla (81 to 101 Mallabdo) who conquest the "Bagri" state (which is at present Midnapur district) and included it Malla state. Kanak Malla (101 to 113 Mallabda) in his reign there was no change in Malla area.Kandarpa Malla (113 to 134 Mallabdo). Sanatan Malla (134 to147 Mallabdo). Kharag Malla was the twelfth ruler of Malla dynasty who was a stronger ruler and faughtvarious battle and extend his area up to Kharag pur railway junction by his name this place was known as Khragpur, who ruled (841 to 862 AD)147to 168 Mallabdo. Kharag Malla succeeded by Durjon Malla(168 to 212 mallabda). Fourteenth ruler was Jadav Malla (212 to 225 Mallabdo)who conquest avillage state neighboring Bishnupur, now it is known as Jadavnagar. Jadav Malla succeeded by Jaganath Malla (225 to 237 Mallabdo) who constructed a Shantinath Shiva temple at Sihar (near Joyrambati). Birat Malla (237 to 252 Mallabdo) was the sixteenth ruler. Madhab Malla (252 to 283 Mallabdo). Ddurgadas Malla (283 to 300 Mallabda). Durgadas Malla succeeded by Jagat Malla(300 to 313 Mallabda)whose region was $994 \mathrm{AD}$ to $1007 \mathrm{AD}$. The nineteenth king of Malla dynasty was JagatMalla and he transferred the capital Pradyumnapur to Bishnupur in (994 AD) 300 Mallabdo.

At present where Pradyumnapur village is situated that is not the historical Pradyumnapur. There is a place which is called "Garh" nearer the south side of the village where the castle erect with prime house. The castle was surrounded by water shed, prince's house, greenery house, prison house, stable, treasury section, elephant house, warrior house were included in the castle. Western side of the castle was guard by the deep forest (now named as Joypur forest). Kanai Shayer was present south of the King's house which is still alive today. In the time of Adi Malla to Durgadas Malla 694 AD to 994 AD (that is 1 Mallabda to 300 Mallabda) 300 years and eighteen rulers were ruled the Mallabhum kingdom from the capital of Pradyumnapur, after that capital was transferred to Bishnupur. So Pradyumnapur (Podompur) was the first capital of Malla dynasty of Mallabhum. Malla dynasty was a Hindu kingdom who was the worshiper of "Bishnu", "Shiva" as well as Durga(Sakta dharma).

\section{References}

1. Chandra Manoranjan - Mallabhum Bishnupur, 2004.

2. Som Charuchandra: Jagrata Devi Dandayswari, 1994.

3. Bankura Parichaya: vol-3, 2012.

4. Bhattachaya Amarsankar: Mouna Mukhar Bishnupur, 2000.

5. Karmakar Phakirnarayan: Bishnupurer Amarkahini, 1979.

6. Dasgupta. S; Biswas. Rabiranjan; Mallik K Goutam: Heritage Tourism: An Anthropological Journey to bishnupur. 2009.

7. Bankura Dist. Gezetter: Ed. Bandyopadhyay A, 1968.

8. Pal Laxmikanta: Kotulpur: Itihas O Sanskriti, 2008.

9. Chaudhury Rathindra Mohan: Bankurajaner Itihas- Sanskriti, 2000.

10. https://www.google.co.in/?gfe $\mathrm{rd}=\mathrm{cr} \& \mathrm{ei}=33 \mathrm{YVWbnCDPDt8Ae917H4DQ \& gws} \mathrm{rd}=\mathrm{ss}$ \#q=list+o f+bengal+ruler+in+mallabhum 